\title{
The Anti-Politics of Development: donor agencies and the political economy of governance
}

\author{
Wil Hout ${ }^{1}$
}

\begin{abstract}
This article discusses the attempt undertaken by several development aid agencies since the turn of the century to integrate political economy assessments into their decision making on development assistance. The article discusses three such attempts: the Drivers of Change adopted by the UK’s Department for International Development, the Strategic Governance and Corruption Analysis (SGACA) developed by the Dutch Directorate General for International Cooperation and the new thinking on political economy analysis, policy reform and political risk advanced by the World Bank. On the basis of a political-economic interpretation of development agencies, two main factors are found to hinder the successful application of political economy assessment. In the first place, the agencies' professional outlook leads them to see development in primarily technical terms. In the second place, the nature of incentives for development professionals leads them to resist the implementation of political economy analyses.
\end{abstract}

Wil Hout is at the International Institute of Social Studies, Erasmus University Rotterdam,PO Box 29776, 2502 LT The Hague, The Netherlands. Email: hout@iss.nl. 


\section{Introduction}

During the 1990s, donor agencies started to realise that development policy involves more than adherence to macro-economic fundamentals, which had been the major precept of the Washington Consensus. The awareness that non-economic factors were important produced a wave of publications on the centrality of 'governance' and led to a focus on institutions.

Under the Post-Washington Consensus, which was a response to the exclusive emphasis of its predecessor on macro-economic policies, the proper organisation of social and political life became the focal point in the thinking about governance and development. The main reflection of the change of focus since the late 1990s was the increasing popularity of the term 'good governance'. Despite the adoption of the term, much of the governance literature - in particular the more policy-oriented work done by of the World Bank - remained grounded in an essentially depoliticised framework. The challenge for policy makers was defined, certainly in the case of the Bank, as 'building institutions for markets'. This concern was epitomised in the title of the 2002 edition of the Bank's flagship publication, the World Development Report. ${ }^{2}$

Following the World Bank’s approach to governance, many development agencies have tended to orientate their governance programmes on relatively technical issues, such as public sector management, public finance and decentralisation. In their support of governance reform programmes, the agencies were preoccupied with the sequencing of reforms rather than with the concrete impacts that such reforms were having on the power relations in the countries concerned. $^{3}$

As argued elsewhere, ${ }^{4}$ many development agencies gradually came to appreciate that governance involves more than a concern with formal mechanisms and institutional arrangements. The agencies started to realise that reality did not conform to the models that were applied. They recognised that power relations and 'informal' patterns of governance were an important factor for explaining why well-intended reforms had not succeeded. They became aware that the analysis of development processes, as well as policy making on and implementation of development assistance, require a better understanding of informal relations and social networks of power.

Calls for a better understanding of underlying power structures and the causes of deeprooted political conflicts - often cast in terms of the need for 'political economy analyses' resulted in the development of various instruments that aim to capture governance realities by 'looking behind the façade'. 5 The attention for political economy was inspired, to a 
considerable extent, by the growing recognition in various development agencies of the limited use of the governance approach that had been adopted under the influence of World Bank thinking, and that was perceived as being highly apolitical.

This article discusses the struggle of the donor community with the application of politicaleconomy analysis to governance issues. In particular, the ensuing discussion focuses on the paradox that donor agencies stress the need to engage in political-economy analyses but, at the same time, appear to be largely unable to use the insights derived from such analyses. The article focuses on three agencies: the UK's Department for International Development (DFID), the Dutch Directorate-General for International Cooperation (DGIS) and the World Bank.

This article argues that an understanding of why development agencies are apparently unable to apply the outcomes of political-economy analysis requires a theoretical interpretation of the very political economy of the aid agencies themselves. This theoretical interpretation needs to take into account the way in which donor agencies function in relation to their environment, as well as the main operational features of those agencies. On the basis of the notions of epistemic communities and organisational incentives, derived from the disciplines of international relations and public administration, the argument of the article is that the difficulty of development agencies to use political economy approaches stems from their conception of what is proper development policy. For most agencies, development is about improving (poor) peoples' livelihoods, either in terms of income or social development indicators (with the Millennium Development Goals as the pinnacle of the current policy consensus). Development policies are conceived, first and foremost, in terms of the instruments to achieve these targets. Agencies are primarily interested in 'doing development', which implies implementing projects and programmes successfully. Although they are concerned about the political context in which they operate, they feel they should not themselves be concerned with politics in their partner countries. The development agencies continue to operate effectively as 'anti-politics machines ${ }^{6}$ and this is why they experience an almost insurmountable difficulty in taking political assessments seriously.

The next section contains an attempt to build a general theoretical political-economy framework on the basis of notions derived from international relations and organisation theory: epistemic communities and organisational incentives. The following three sections then analyse the instruments for political-economy analysis that were introduced by the three development agencies mentioned above: the Drivers of Change adopted by DFID, the 
Strategic Governance and Corruption Analysis (SGACA) developed by DGIS and the new thinking on political economy analysis, policy reform and political risk advanced by the World Bank. The final section formulates some conclusions.

\section{Understanding Donor Agencies}

The continuing discussion on the purposes of aid indicates that the jury is still out on the question as to what motivates governments to give aid. As Lancaster has made clear in her much-cited work on foreign aid, 'development' is clearly only one among various purposes of aid. ${ }^{7}$ On the basis of a set of key policy documents of leading international development agencies, former ODI Director Simon Maxwell has usefully summarised the key elements of the current development agenda as a 'new meta-narrative'. According to Maxwell, the new mantra of development assistance is characterised by acceptance of the Millennium Development Goals as an 'over-arching framework', linking these to national Poverty Reduction Strategies, which are to be endorsed by World Bank and IMF, 'sound' macroeconomic policies and trade liberalisation, proper public expenditure management and harmonised aid aimed at improving governance. ${ }^{8}$

Recent accounts of development agencies have stressed that the professionals working in these organisations often find it difficult to come to terms with politics in the countries they are posted to. ${ }^{9}$ One major cause of the seemingly apolitical orientation of many development professionals is that they are part of an 'epistemic community' that is motivated by the common endeavour of reducing or eradicating poverty and empowering the poorest parts of the population in developing countries. ${ }^{10}$ Development agencies work on the basis of a shared set of understandings of and values about processes of development. Their 'institutional ethos' derives mainly from their commitment to 'making poverty history' and improving the quality of life of people in developing countries. ${ }^{11}$ With this commitment comes an interest in 'doing development', which is equated with implementing projects and programmes successfully. Although staff are concerned about the political context they operate in, they usually feel they should not themselves be concerned with politics in the partners countries. As James Ferguson pointed out over two decades ago, most development agencies continue to operate effectively as 'anti-politics machines', which explains why they experience great difficulty in taking political analyses seriously. ${ }^{12}$

Furthermore, the nature of the work of development agencies implies that their staff is subject to particular incentive structures. As they dealing with complex realities, it is hard for 
development agencies to define and measure their output. Despite the recent emphasis of aid effectiveness, the main instruments for aid agencies to monitor performance of individual staff members remain linked to the commitment and disbursement of funds - 'moving money', as Easterly ${ }^{13}$ called it -, the management of projects and programmes and the production of reports and memos. ${ }^{14}$ To the extent that assessment of results is possible, project and programme evaluations are usually very time consuming and their findings get published long after the fact. ${ }^{15}$ The focus of incentives for staff of aid bureaucracies on observable outputs such as disbursement activity, management and written work, brings about an orientation of staff on the technical aspects of their work, as their advancement within the organisation depends on assessments of their performance in financial and project or programme management. Overall, there seem to be very few incentives for staff to learn from past activities and gain in-depth knowledge about the country they are working in. ${ }^{16}$

Next to the implications of the internal working of development agencies on staff behaviour, changes in the external political environment of such agencies have led to the prevalence of more a technocratic outlook among managers and decision makers. Concerns about the effectiveness of development assistance policies, coupled with a general move to enhanced 'accountability’ of government agencies, have led to the introduction of monitoring and evaluation tools deriving from New Public Management. So-called 'new development management ${ }^{, 17}$ spurred the adoption of techniques that aim at minimising risk and controlling the behaviour of public servants. Examples of this trend are the mushrooming of evaluations labelled 'evaluitis' by Frey ${ }^{18}$ - and the introduction of new accountability instruments such as the Public Service Agreements for international development in the United Kingdom and the spread of a 'counter-bureaucracy' aimed at the management of aid programmes in the United States. ${ }^{19}$ The techniques of 'new development management' enhance the inherent technocratic orientation of development agencies, as a larger part of their resources need to be devoted to establishing the measurable results of their work. There is a risk that the attention for activities with easily measurable results stands in the way of more complex endeavours - such as those related to the political economy of the partner country -, the results of which are not easy to determine. ${ }^{20}$ There is a strong tendency for agencies to become concerned primarily with how things are done, while what is done is of secondary importance.

\section{Drivers of Change ${ }^{21}$}


The Blair Government’s 1997 White Paper, Eliminating World Poverty, stressed the contribution of improved governance in developing countries to achieving development targets. 'Governance' in the early days of the Blair government was defined in largely instrumental terms and was seen to involve several 'key capabilities for the state', related to accountable government, macroeconomic stability, conditions for private sector investment and trade, pro-poor policies, public service delivery, personal and national security, access to justice and anti-corruption. $^{22}$

The need for a political economy approach to governance issues was identified at the UK's Department for International Development (DFID) in 1999, when the Head of the Governance Department, conceived a research project on 'responsiveness of political systems to poverty reduction'. ${ }^{23}$ The idea underlying this project was that poor performance of countries on poverty reduction required an explanation related to the functioning of political systems, with particular attention for the role of accountability. ${ }^{24}$ The concern with politics led DFID's Governance Department to the development of an approach called Change Forecasting, the objective of which was to identify whom among the political elite in developing countries would be interested in governance reforms, and who would not be committed to change. ${ }^{25}$

On the basis of these first steps, DFID launched the so-called Drivers of Change (DoC) framework with an analysis of the 'drivers of pro-poor change' in Bangladesh in $2002 .{ }^{26}$ The direct reason for the introduction of Drivers of Change was the feeling at DFID that it would not be sufficient for donor agencies 'to bring about change through technically sound programmes, supported in country by individual champions of reform or change'. ${ }^{27}$ In addition to such programmes, it was argued, knowledge would be required about governance realities on the ground in developing countries, in particular related to the role of formal and informal institutions and 'underlying structural features' shaping governance practices. The Drivers of Change methodology responded to 'DFID’s need to understand economic, political and social contexts, in other words, the application of political economy analysis to formulation of donor strategy and implementation'. ${ }^{28}$

Between June 2003 and September 2004, a Drivers of Change team funtioned within the Policy Division at DFID headquarters, which primarily served to facilitate analyses at country level and did not impose a single methodology. After September 2004, a much smaller policy team was set up only for coordination activities. ${ }^{29}$ Thus, the Drivers of Change programme typically led to the commissioning of analyses by DFID country offices from teams of 
independent local and international consultants. Altogether, consultants have produced some twenty-five reports ${ }^{30}$ that all followed the programme's broad conceptual model.

By analysing three different aspects of economic, political and social contexts (agents, structural features and institutions), the Drivers of Change methodology attempted to uncover the factors that contribute to or impede change. Agents are individuals and organisations pursuing particular interests, including political elites, the judiciary, the military, civil society organisations and the media. Structural features relate to 'deeply embedded' factors as the history of state formation, natural resources, economic and social structures, and urbanisation. Institutions are the formal and informal 'rules governing the behaviour of agents', and range from laws and official procedures to social and cultural norms. ${ }^{31}$ As Mustaq Khan has noted in a review of various Drivers of Change studies, the common assumption underlying those studies seems to have been that certain 'good governance reforms' are a prerequisite for further development and transformation in aid-receiving countries. ${ }^{32}$ The main issues appeared to be the sequencing of reforms and the identification of the change agents to bring about such governance reforms.

Assessments of the Drivers of Change approach have pointed at various weaknesses that limited the usefulness of the framework. In a review of the first twenty reports, Leftwich focused on the lack of rigour underlying the Drivers of Change studies. ${ }^{33}$ He noted that the studies performed under the broad umbrella of Drivers of Change displayed considerable variance in the use of central concepts such as agents, structural features and institutions. Moreover, Leftwich argued, the studies did not produce a convincing view on possible dynamics of change, as the interrelations among agents, institutions and structures were not well specified. Finally, Leftwich indicated that there was not a clear, shared understanding among the Drivers of Change analyses of what 'political economy' actually is.

Various commentators have argued that several factors limited the applicability of the Drivers of Change approach to programming exercises and concrete policy decisions. ${ }^{34}$ Importantly, the timing of Drivers of Change studies was often not well aligned with the preparation of DFID’s country programmes. Further, many Drivers of Change analyses proved to be highly descriptive, oriented to specific local political processes and did not provide operational conclusions. ${ }^{35}$

The history of the Drivers of Change approach indicates that its initial driving force was located at DFID headquarters, within the Governance Department, and that the method was soon left to the country offices. At the country level, particular DFID staff members turned 
out to be champions of the approach in later years. Yet, despite the fact that they found the analyses useful to get a better understanding of the local political economy, the approach did not provide them with solutions for the dilemmas they faced in their day-to-day work and played a limited role in the revision of country strategies. ${ }^{36}$ In the end, Drivers of Change analyses appear to have run up to the limitations of the practical nature of development work, where staff feel pressure to increase spending and work on programmes in the light of the Millennium Development Goals.

The lofty goals of understanding realities better may thus 'not be well aligned with donor incentives to demonstrate short term impact, respond to their own taxpayers and lobby groups, and to spend the allocated aid resources'. ${ }^{37}$ Moreover, for individual staff members

internal, organisational incentives [supporting] continued development and implementation of DOC work ... are relatively weak [and require] more visible support from senior staff, as well as changes in human resource management systems, in order to demonstrate (through performance assessment, promotions and postings) that skills in political analysis, and country level knowledge, are valued and rewarded. ${ }^{38}$

The conclusion must, then, be that Drivers of Change has served mainly as a means for enhancing the understanding of staff at DFID country offices and country specialists at headquarters about the political-economic realities in partner countries. ${ }^{39}$ The approach has failed to have a lasting impact on policy making, as is reflected in its apparent disappearance in recent years.

\section{The Strategic Governance and Corruption Analysis}

Dutch policy making on development has demonstrated a commitment to principles of 'good governance' ever since the arrival of social-democrat Eveline Herfkens as Minister for Development Cooperation in 1998. Herfkens, who had previously served as Executive Director at the World Bank, changed the orientation of Dutch development assistance by embracing aid selectivity, in that a limited set of countries were chosen for Dutch bilateral development assistance on the basis of 'the presence of good policies and good governance in the recipient countries'. 40

Subsequent Ministers for Development Cooperation (christian-democrat Agnes van Ardenne and social-democrat Bert Koenders) increased the number of Dutch partner countries 
from 22 to over 30, while maintaining a concern with governance in aid-recipient countries. Koenders considered 'good governance' to be 'a huge boost for development', ${ }^{41}$ and emphasised that a 'more political conception of good governance' should be applied. ${ }^{42}$ His call for a political strategy for good governance was grounded in attention for the 'context' that influences the success of policies aimed at fighting corruption, strengthening the rule of law and building democracy. ${ }^{43}$

The so-called Strategic Governance and Corruption Analysis (SGACA), which had been conceived by the Directorate-General for International Cooperation at the Dutch Ministry of Foreign Affairs in 2006 and was introduced in 2007, resonated well with Koenders' views on governance. Despite the Minister's enthusiasm for the new tool, SGACA appears to have had a similar fate as the Drivers of Change approach. SGACA was introduced by the Human Rights, Good Governance and Humanitarian Aid (DMH) Department with the clear aim of integrating the analysis with standard policy making procedures at the Ministry. The instrument was given a role in the design of Multi-annual Strategic Plans per embassy with the intention of enhancing the 'operational' value of the analyses.

The introduction of SGACA took place after a lengthy period of internal discussions at the Ministry about the proper way to integrate governance-oriented concerns into Dutch development policy, during which the need to understand 'informal' governance processes was expressed very clearly. ${ }^{44}$ The main champion of SGACA was the Ministry of Foreign Affairs’ DMH Department. After a period of rivalry with the Department for Effectiveness and Quality (DEK), the two Departments agreed that their mutual involvement with 'good governance' would be solved by a division of labour: where DMH would deal with issues of 'legitimacy', DEK would be in charge of 'effectiveness' ${ }^{45} \mathrm{DEK}$, which had been the Ministry's primary responsible for the provision of macro-economic (budget) support, for instance as part of debt relief, had developed the 'track record' instrument for ascertaining the degree to which partner countries would qualify for general or sectoral budget support. ${ }^{46}$ DEK displayed a generally sceptical attitude towards the SGACA approach, as they felt that the results of political economy analyses, which zero in on accountability mechanisms and practices of corruption, could impact on the attitude in Parliament towards the provision of budget support. ${ }^{47}$

The starting point of the SGACAs was the so-called Power and Change Analysis (PCAs), which would be a political-economy assessment aiming to bring out what are the determinants, in state-society relationships, of countries' governance problems. According to 
the SGACA framework, the 'underlying assumption' of the analysis is 'that building more effective, accountable states and public institutions requires a political process of interaction between the state and (organised groups in) society'. ${ }^{48}$

The SGACAs' Power and Change Analyses addressed, in a similar way as the Drivers of Change studies, three aspects of the political economy of aid-receiving developing countries: the 'foundational factors', the 'rules of the game' and the 'here and now' (the current context and main actors and stakeholders). ${ }^{49}$ The approach envisaged that operational implications would be derived from the SGACAs during workshops organised at the embassies. ${ }^{50}$ As it was put in the SGACA framework:

The PCA can help with refining existing choices or making new ones, by enhancing understanding of context (the underlying causes of bad governance and weak development); and highlighting opportunities and threats arising from that context that should inform all donor interventions. ${ }^{51}$

The first of 29 completed SGACA exercises started from the assumption that the Power and Change Analyses would be 'quick scans', on the basis of governance assessments made by the Dutch embassies (the so-called 'track records', see above) and other readily available material. A pilot project, in the second quarter of 2007, led to an increase of the time allocated to the work of the international and local consultants in order to provide more solid analyses.

Despite the increase of resources allocated to the analyses, interviews ${ }^{52}$ with direct observers of the SGACA exercises indicate that the quality of the SGACAs has been highly variable. In certain cases, the limited expertise of the consultants was mentioned as a cause of poor quality, while in other cases the relative failure of SGACAs was ascribed to the lack of interest among embassy staff. Most observers agree that the decision by the Minister for Development Cooperation to bring the drafting of the Multi-annual Strategic Plans (MASPs) for 2009-2012 forward had important negative impacts on the SGACA process. As fewer than half of all 29 SGACAs had been completed by the time the MASPs were finalised at the beginning of 2008, most SGACA reports failed to feed into decision making on multi-annual programming.

The lack of support for the SGACA exercises seems, at least in part, due to a similar logic that was noted in the section on Drivers of Change above. The scepticism at the Department for Effectiveness and Quality is an expression of the common 'bureaucratic politics' that 
exists in any Ministry and that is related to the perceived threats emanating from projects undertaken by other Departments. In addition to this, regional Departments in the Ministry of Foreign Affairs expressed their fear that the analysis of the political-economic reality of partner countries would damage their relationships with governments. ${ }^{53}$ Similar fears were present at Dutch embassies in the partner countries, as they undoutedly felt the threat of political fallout from reports on patronage and corruption on their budget support to country governments, and these added to the feelings of a general lack of ownership at the embassies. A good number of embassy staff saw the SGACA exercise as an imposition by the headquarters in The Hague, which interfered with their normal way of doing development business in the partner country. Passive resistance during the planning of SGACAs and reluctance to participate actively in the implementation of the political economy analyses were the main signs of the lack of ownership at embassy level. The SGACA end-of-project review summed up the embassies' attitude to the exercises by comparing them to a trip to the dentist: they were seen as 'something to be endured and ideally to be as short as possible'. ${ }^{4}$ The outcome of bureaucratic quibbles at headquarters and lack of support throughout the organisation was also noted by one senior consultant, who made quite a damning statement about the exercise:

Fundamentally, implementation was the main problem, as there were internal problems within the ministry, as well as problems in the relationship between Departments. Ministry staff basically had no idea as to how really address governance issues. People never got seriously down to analysing what type of changes would be needed. Apart from the Minister's commitment, there was no leadership within the organisation to implement SGACA and the governance programmes. The process was not just mismanaged, it was not managed at all. ${ }^{55}$

The SGACA process came to an end only little more than three years after its inception. The Human Rights, Good Governance and Humanitarian Aid Department has been considering an 'action plan' in order to bring the usefulness of 'political economy thinking' to the attention of embassy staff, but this idea has been abandoned in early 2010. Instead of the action plan, a set of briefing papers on the salient components of the SGACA exercise has been produced for staff at Dutch embassies and at the Ministry. ${ }^{56}$ The fate of SGACA seems, therefore, rather similar to that of the Drivers of Change, as its main value is seen to derive 
from the contribution that political economy analysis has on the understanding of embassy staff regarding interests and power struggles in the partner countries.

\section{Political Economy Analysis, Policy Reform and Political Risk}

The World Bank has come a long way in its thinking about the political economy of governance practices. During the 1990s, the Bank was leading the introduction of notions of governance to the development discourse, in recognition of the failure of the purely macroeconomic focus of the 'Washington Consensus'. The World Bank's engagement with governance showed an attempt to avoid political aspects by arguing that 'governance may be relevant to the Bank's work if it is addressed in terms of having good order and discipline in the management of a country's resources'. ${ }^{57}$

The World Development Report 2002 was premised on the notion that markets are the central element of development: 'income from participating in the market is the key to boosting economic growth for nations and to reducing poverty for individuals' ${ }^{58}$ The main challenge in fighting poverty was almost reduced to a micro-economic issue: it would involve creating opportunities and incentives for poor people to make use of markets. ${ }^{59}$ 'Good governance' precepts would limit the role of the state to that of a regulator. The World Development Report 2002 distinguished four elements, in particular, as tasks of a wellgoverned state: the securing of property rights, regulation aimed at promoting competition, macro-economic policies for stimulating market activity, and the fight against corruption. ${ }^{60}$

In a self-assessment published in 2005, the World Bank embraced some significant conceptual and theoretical innovations that contained an implicit criticism of and distancing from its earlier apolitical, technocratic approach. Interestingly, the self-assessment argues:

Perhaps the most important lesson of the 1990s is that technocratic responses to improve governance work only in very auspicious settings - where there is committed leadership, a broadly based coalition in support of reform, and sufficient capacity to carry the reform process forward. ... Meeting the challenge requires a good understanding of the political dimensions of reform, and, in particular, of how reform can be used to identify and build constituencies that are capable of sustaining the reform momentum. ${ }^{61}$ 
Although the report seemed to display much greater sensitivity to political dynamics than in the past, the 'guidelines' for policy reform as formulated by the Bank remained limited to the creation of incentives for economic actors, the pursuit of growth strategies and the creation of institutional conditions for a favourable investment climate. ${ }^{62}$

More recent approaches presented by the World Bank appear to signal a change in orientation. In particular, a report of the Social Development Department and a so-called 'good practice framework', published by the World Bank's Poverty Reduction and Economic Management (PREM) Network stand out as representatives of seemingly new thinking on political processes within the Bank. ${ }^{63}$ Given the interpretation of the overall orientation of the development community and the incentives inherent to their functioning, it is, however, doubtful whether the Bank's new ideas will produce more than 'the next "fix", limited to a narrow and fairly mechanistic kind of stakeholder analysis' ${ }^{64}$

The Social Development Department's approach to the political economy of policy reform is based on Poverty and Social Impact Analysis in specific sectors, such as agriculture and water. The 'political economy of reform' revolves around three distinctive elements: the reform context, the reform arena and the reform process. ${ }^{65}$ The reform context relates to the socio-economic, political, cultural and historical institutions that impact on reform. The reform arena includes societal 'rules of the game', stakeholders and their interests. The reform process refers to 'information flows, voice and public debate' that determine who sets the agenda for reform and how proposed policy changes are communicated. ${ }^{66}$ Together, the three elements set an 'action framework' that comprises elements such as: the timing and sequencing of reforms, analysis of the 'demand and supply' of reform in order to build coalitions for change, and partnership and public communication strategies. ${ }^{67}$ The ultimate aim of the political economy of policy reform appear to be to assess 'the most significant political economy and political risks to policy reform'. By gaining knowledge on how political economy and political 'variables' impact on the outcome of reform processes, development agencies should increase their options for influencing the political-economic risks and opportunities. ${ }^{68}$

In line with the political economy of policy reform, the PREM Network's 'problem-driven governance and political economy analysis' is also set up in order to enhance the effectiveness of the Bank's interventions. ${ }^{69}$ The Bank, so much is clear from the framework, stresses the instrumental nature of its approach, as governance and political economy analysis 
can help to anticipate and manage risks - including risks of reform failure, of Banksupported reforms triggering unintended negative consequences, as well as potential reputational risks. It can also assist in transmitting important knowledge about institutions and stakeholders more quickly and effectively to staff newly joining a country or other operational team. ${ }^{70}$

In line with most other approaches, 'problem-driven governance and political economy analysis' distinguishes three 'clusters of drivers': structures, institutions and actors or stakeholders. ${ }^{71}$ Together, these clusters impact on political and public sector action and, ultimately, on the outcomes of policies, such as growth, poverty reduction and provision of public goods.

The problem-driven nature of the approach is linked to its focus on specific problems or issues that appear to be spurred by particular 'governance and political economy weaknesses'. On the basis of the identification of such problems, the approach would proceed to the second 'layer' of uncovering the institutional and governance arrangements in society and 'drill down' to the third 'layer' where the three mentioned clusters of political economy drivers represent obstacles to change, or opportunities for reform. ${ }^{72}$ The bottom-line of the problemdriven approach is that reform proposals should be 'feasible'. Rather than advocating allencompassing governance reform, 'good enough governance' should be the focus of development agencies. ${ }^{73}$

Although the framework alludes to 'country-level analysis', specific sectors and policy themes receive most attention. ${ }^{74}$ It is at this level that the framework seems to see the best opportunities for the application of governance and political economy analysis. In particular, the authors of the framework suggest three options to the Bank. In the first place, analyses would inform Bank staff teams how to adjust strategies and operations to existing opportunities for change. Further, such analyses would enhance and broaden the policy dialogue with country governments. Finally, findings of the governance and political economy analyses would point out opportunities for supporting change proactively. ${ }^{75}$

On the basis of the two political economy approaches propagated in World Bank circles, one is led to conclude that the changes to the Bank's approach, if any, have taken largely an instrumental character. Unsworth's expectation that a predominantly 'mechanistic kind of stakeholder analysis ${ }^{76}$ would prevail has, so far, not been falsified. The above discussion has made clear that knowledge about the political economy of borrowing countries is considered 
relevant mostly for judging what are the main limits to implementing policy reform, and how political risks can be minimised. The World Bank’s earlier plea, in the stock-taking exercise of 2005 (quoted above), that more attention should be paid to the 'political dimensions of reform' seems to have had only limited impact on its day-to-day operations. The World Bank's operations in the developing world through the International Development Association have remained 'business as usual'. It remains to be seen whether 'political economy’ will change Bank practices in the future.

The Bank’s application of the Country Policy and Institutional Assessment (CPIA) may illustrate the limited impact that political economy analysis has had so far for the Bank's policy on lending to developing countries. The CPIA, which was introduced at the end of the 1990s in order to render IDA allocations more sensitive to recipient countries’ reform of policies and governance, has been one of the most fiercely criticised instruments in international development financing. ${ }^{77}$ Much of the criticism of the instrument centres on its neo-liberal, market-oriented bias. Despite a recent revision of the CPIA methodology, assessments of country performance in the 2008-11 period are being determined, for about two-thirds, by a governance-related cluster of five measures. ${ }^{78}$ These measures are:

- property rights and rule-based governance;

- quality of budgetary and financial management;

- efficiency of revenue mobilization;

- quality of public administration; and

- transparency, accountability and corruption in the public sector.

Thus, the emphasis of IDA's governance assessments continues to be on impediments for private-sector activity, on public sector management in relation to public finance, taxation and service delivery, and on checks on government. There are no signs that the allocation of loans to developing countries has become less performance-based and less reliant on the technocratic and market-oriented CPIA. Further, it is not clear how the change in thinking on political economy analysis is reflected in actual lending practices, nor how the awareness of political dimensions of reform is featured into projects and programmes aimed at strengthening governance in developing countries. On the basis of information that is available at the time or writing, the changes advocated in the two new political economy frameworks seem to have little impact on day-to-day World Bank policy practices. 


\section{Conclusion}

The discussion in this article of various approaches to political economy analysis has indicated that such instruments do not sit very comfortably among the range of tasks undertaken by development agencies. The unease of development agencies does not seem to derive from the objectives of this type of analysis - which is generally understood and endorsed, at least at the level of policy-makers at headquarters - but is a consequence of the way in which the agencies define their own tasks, and of the internal operation that is a result of the structure of their organisational interests.

Three examples (the UK’s Drivers of Change, the Dutch Strategic Governance and Corruption Analysis and the World Bank’s approaches to political economy analysis) have been discussed in the article. Despite their pretensions the former two approaches did not produce many concrete results in terms of day-to-day policy making. The Drivers of Change and the SGACA in the end seemed mainly to serve for enhancing the understanding among embassy or country office staff of the political-economic realities in the countries they are posted to. Vagueness of the methodologies appears to have been a factor contributing to the limited use of the approaches, as was the lack of operational embedding. The launching by the World Bank of a political economy framework has not appeared to have changed dramatically the way the Bank is dealing with governance issues. Its sectoral application of political economy analysis seems to be 'inward-looking', in that it aims to limit the risk of reform failure and reputational risk. The increased attention for political aspects of governance, which dates back at least to a major self-assessment published in 2005, has not impacted on the way the Bank deals with lending to developing countries, as the IDA's main diagnostic tool remains biased to technocratic and market-oriented performance indicators.

The examples illustrate that development agencies have many traits of an epistemic community, which implies that their staff have a more or less common outlook on the world and share a set of values and norms related to poverty reduction and advancing development in countries of the global South. This outlook leads to a rather instrumental approach to development programmes and projects, which tends to pay little attention to political struggles and power relations and defines governance in predominantly a-political terms. Staff are motivated, in the first place, by 'doing development' in a professional way, which implies choosing the best instruments for obtaining a maximum of results.

In addition to their shared norms and values, the structure of incentives within development agencies is an important determinant of the outlook of development 
professionals on the issue of politics. For staff, 'doing development' implies managing and implementing programmes and projects, and disbursing funds to partner organisations predominantly governments, but also others - in order to obtain results. The depoliticised understanding of development is instrumental for development professionals, as this helps them focus on the key elements of their work, without being 'distracted' by the potential conflicts of interest among their partners and the power implications of development processes.

The technocratic and a-political framing of governance will not, of course surprise readers of the work of well-known authors such as James Ferguson and John Harriss. Ferguson, who focused on the implementation of development policies in Lesotho, and Harriss, who analysed the usage of 'social capital' by the World Bank, pointed out already long ago that the international development community is operating as an 'anti-politics machine'. ${ }^{79}$ More recently, Sue Unsworth, the former Chief Governance Advisor at the UK's Department for International Development, argued that donor agencies find it inherently 'hard to come to terms with politics, ${ }^{80}$

The tension between the fundamentally depoliticised understanding of governance and the call for political sensitivity should probably be acknowledged as one of the inherent characteristics of 'Aidland'. ${ }^{81}$ Those responsible for policy-making on development assistance, usually at headquarters, generally recognise the need for more fundamental, political or political-economy, analysis of development reality behind the 'façade' of formal political institutions. People out 'in the field', however, will generally understand that interests are part of the development process, but tend to set the priorities for their own dayto-day activities differently under the influence of the incentives that have been discussed above. Although the current framework of international development seems to require a 'political understanding of aid delivery' by development agencies, ${ }^{82}$ it is unlikely that the persistent emphasis on 'doing development' will give way to a more profound engagement with politics. The irony is that as long as development practice is seen as an expert activity, not an act of politics, the development 'industry' will continue to operate as the 'anti-politics machine' that it has always been. ${ }^{83}$

\section{Notes}

\footnotetext{
${ }^{1}$ The research for this article was performed as part of a project on 'Achieving Sustainable Demand for Governance: Addressing Political Dimensions of Change’, financed by an Australian Development Research
} 
Award. I would like to thank Richard Robison, the project director, Andrew Rosser and other participants in the December 2010 ADRA conference in Fremantle for their comments on an earlier version of this chapter.

${ }^{2}$ World Bank, Building Institutions for Markets: World Development Report 2002, New York: Oxford University Press, 2002.

${ }^{3}$ Cf R Robison, 'Strange Bedfellows: Political Alliances in the Making of Neo-liberal Governance', in W Hout \& R Robison (eds), Governance and the Depoliticisation of Development, London: Routledge, 2009, pp 15-28.

${ }^{4}$ W Hout \& R Robison, 'Development and the Politics of Governance: Framework for Analysis', in W Hout \& R Robison (eds), Governance and the Depoliticisation of Development, London: Routledge, 2009, pp 2-3.

${ }^{5}$ This is a term used, among others, by K Harth \& J Waltmans, 'Behind the Façade: The Informal Reality in Developing Countries', in Ministry of Foreign Affairs, A Rich Menu for the Poor: Food for Thought on Effective Aid Policies, Essay 3, 2007, at http://www.minbuza.nl/dsresource?objectid=buzabeheer:48063\&type=org (accessed 7 October 2011) and J Waltmans, 'Behind the Façade: From Analysis to Action', in Ministry of Foreign Affairs, A Rich Menu for the Poor: Food for Thought on Effective Aid Policies, Essay 15, 2008, at http://www.minbuza.nl/dsresource?objectid=buzabeheer:48075\&type=org (accessed 7 October 2011).

${ }^{6}$ Cf J Ferguson, The Anti-Politics Machine: 'Development', Depoliticization, and Bureaucratic Power in Lesotho, Cambridge: Cambridge University Press, 1990.

${ }^{7}$ C Lancaster, Foreign Aid: Diplomacy, Development, Domestic Politics, Chicago: University of Chicago Press, 2007, pp 12-18.

${ }^{8}$ S Maxwell, The Washington Consensus is Dead! Long Live the Meta-narrative! Working Paper 243, London: Overseas Development Institute, 2005, p 1.

${ }^{9}$ S Unsworth, 'What's Politics Got to Do with It? Why Donors Find it so Hard to Come to Terms with Politics, and why This Matters', Journal of International Development, 21(6), 2009, pp 883-942; A de Haan \& M Everest-Phillips, Can New Aid Modalities Handle Politics? Research Paper 2007/63, Helsinki: UNU-WIDER, 2007.

${ }^{10}$ According to Haas, an epistemic community is 'a network of professionals with recognized expertise and competence in a particular domain and an authoritative claim to policy-relevant knowledge within that domain or issue-area'. See: PM Haas, 'Introduction: Epistemic Communities and International Policy Coordination', International Organization, 46(1), 1992, pp 1-35.

${ }^{11}$ Unsworth, 'What's Politics Got to Do with It?', p 890.

${ }^{12}$ Ferguson, The Anti-Politics Machine.

${ }^{13}$ W Easterly, 'The Cartel of Good Intentions: The Problem of Bureaucracy in Foreign Aid', Journal of Economic Policy Reform, 5(4), 2002, p 228.

${ }^{14}$ Cf CC Gibson, K Andersson, E Ostrom \& S Shivakumar, The Samaritan's Dilemma: The Political Economy of Development Aid, Oxford: Oxford University Press, 2005,pp 134-5, 154-6; J Carlsson, G Köhlin \& A Ekbom, The Political Economy of Evaluation: International Aid Agencies and the Effectiveness of Aid, New York: St Martin’s Press, 1994, p 5; J van Gastel \& M Nuijten, “The Genealogy of the "Good Governance” and “Ownership” Agenda at the Dutch Ministry of Development Cooperation', in D Mosse \& D Lewis (eds), The Aid Effect: Giving and Governing in International Development, London: Pluto Press, 2005, p 98.

${ }^{15}$ Gibson et al., The Samaritan's Dilemma, pp 151-4.

${ }^{16}$ Ibid, p 144 on the practices at SIDA.

${ }^{17}$ B Cooke \& S Dar, 'Introduction: The New Development Management', in S Dar \& B Cooke (eds), The New Development Management: Critiquing the Dual Modernization, London: Zed Books, 2008, pp 1-17.

${ }^{18}$ BS Frey, 'Evaluierungen, Evaluierungen ... Evaluitis', Perspektiven der Wirtschaftspolitik, 8(3), 2007, pp 207-20.

${ }^{19}$ Cf Natsios, The Clash of the Counter-bureaucracy and Development, Center for Global Development Essay, July, Washington, D.C.: Center for Global Development, 2010, p 5.

${ }^{20}$ Cf A Saith, 'From Universal Values to Millennium Development Goals: Lost in Translation', Development and Change, 37(6), 2006, pp 1167-99.

${ }^{21}$ This section draws on L Schakel, W Hout, A Slob \& D Smith, The Use of Political Economy Assessment Instruments in the Governance Sphere, ECORYS Research Progamme Report, Rotterdam: ECORYS Nederland, 2010.

${ }^{22}$ Department for International Development, Making Government Work for Poor People: Building State Capability, Strategy Paper, London: Department for International Development, 2001, p 12.

${ }^{23}$ M Moore \& J Putzel, Thinking Strategically About Politics and Poverty, IDS Working Paper 101, Brighton: Institute of Development Studies, 1999, at http://www.ntd.co.uk/idsbookshop/details.asp?id=509 (accessed 7 October 2011).

${ }^{24}$ R Wilson, Promoting Good Governance: Some Lessons from History and Recent Experience, Audio Recording, 12 June 2002, London: Overseas Development Institute, part 3, at 
http://www.odi.org.uk/events/details.asp?id=2132\&title=promoting-good-governance-lessons\#details (accessed 7 October 2011)

${ }^{25}$ Wilson, Promoting Good Governance, part 6.

${ }^{26}$ A Duncan, I Sharif, P Landell-Mills, D Hulme \& J Roy, Bangladesh: Supporting the Drivers of Pro-poor Change, 2002, at http://www.gsdrc.org/docs/open/DOC7.pdf (accessed 7 October).

${ }^{27}$ Department for International Development (2004) Drivers of Change, Public Information Note, 2004, p 1, at http://www.gsdrc.org/docs/open/DOC59.pdf (accessed 7 October 2011).

${ }^{28}$ D Warrener, The Drivers of Change Approach, Synthesis Paper 3, London: Overseas Development Institute, 2004, p 1.

${ }^{29}$ T Dahl-Østergaard, S Unsworth, M Robinson \& RI Jensen, Lessons Learned on the Use of Power and Drivers of Change Analyses in Development Co-operation, Review Commissioned by the OECD DAC Network on Governance, 2005, p 4, at http://www.gsdrc.org/docs/open/DOC82.pdf (accessed 7 October 2011).

${ }^{30}$ The overview of Drivers of Change country studies at the GSDRC website mentions studies on: Angola, Bangladesh, Bolivia, Cambodia, the Democratic Republic of Congo, Ghana, Kenya, Kyrgyzstan, Malawi, Mozambique, Nigeria, Pakistan, Peru, Tanzania, Uganda, Vanuatu and Zambia (at http://www.gsdrc.org/index.cfm?objectid=597A76DB-14C2-620A-2770D688963DF944\#doc, accessed 7 October 2011).

${ }^{31}$ Department for International Development, Drivers of Change,p 1.

${ }^{32}$ MH Khan, Review of DFID’s Governance Target Strategy Paper, 2005, p 38, at http://mercury.soas.ac.uk/users/mk17/Docs/Review\%20of\%20Dfid\%20Governance\%20TSP.pdf (accessed 7 October 2011).: 38)

${ }^{33}$ A Leftwich, Drivers of Change: Refining the Analytical Framework, Part 1: Conceptual and Theoretical Issues, 2006, pp 17-20, at http://www.gsdrc.org/docs/open/DOC103.pdf (accessed 7 October 2011). Cf Khan, Review of DFID's Governance Target Strategy Paper, pp 5-6.

${ }^{34} \mathrm{~N}$ Thornton \& M Cox, Review of the Uptake of the Drivers of Change Approach, London: Agulhas Development Consultants, 2005; Dahl-Østergaard et al, Lessons Learned on the Use of Power and Drivers of Change Analyses.

${ }^{35}$ Dahl-Østergaard et al, Lessons Learned on the Use of Power and Drivers of Change Analyses, p 11; Thornton and Cox, Review of the Uptake of the Drivers of Change Approach, pp 6, 22-3; V Chhotray \& D Hulme, 'Contrasting Visions for Aid and Governance in the 21st Century: The White House Millennium Challenge Account and DFID’s Drivers of Change’, World Development, 37(1), 2009, p 45.

${ }^{36}$ Dahl-Østergaard et al, Lessons Learned on the Use of Power and Drivers of Change Analyses, pp 15-17.

${ }^{37}$ Ibid, pp 26-7.

${ }^{38}$ Ibid, p 19.

${ }^{39}$ Ibid, p 7.

${ }^{40}$ Minister for Development Cooperation, Brief met beleidsvoornemens inzake toepassing van criteria op het vlak van de structurele bilaterale ontwikkelingshulp [Letter to Parliament on the Application of Criteria Related to Structural Bilateral Development Assistance], Second Chamber, 1998-99 Session, 26200V, no. 8, p 2 (my translation).

${ }^{41}$ AG Koenders, International Cooperation 2.0: Agenda for Modern Poverty Reduction, Lecture at the University of Amsterdam, 8 November 2008, p 9, at http://www.minbuza.nl/en/News/Speeches_and_Articles/2009/February/International_cooperation_2_0 (accessed 7 October 2011).

${ }^{42}$ AG Koenders, Democracy and Development: Thinking Forward, Lecture for the Society for International Development, 14 September 2007, p 9, at http://www.minbuza.nl/en/News/Speeches_and_Articles/2007/09/Democracy_and_Development_Thinking_For ward (accessed 7 October 2011).

${ }^{43}$ Koenders, Democracy and Development, p 6.

${ }^{44}$ Harth \& J Waltmans, 'Behind the Façade'; Waltmans, 'Behind the Façade'.

${ }^{45}$ Personal communication by a staff member of the Department for Human Rights and Peace Building (DMH’s predecessor), The Hague, 15 May 2006

${ }^{46}$ The track record, which was designed in the mid-1990s to assist the Ministry with decisions on macroeconomic support, has evolved into an instrument to judge whether countries qualify for particular aid modalities. The track record consists of four clusters: poverty reduction, economic order, good governance and policy dialogue. The Dutch embassies score the performance of partner countries on two criteria per cluster. See W Hout, The Politics of Aid Selectivity: Good Governance Criteria in World Bank, US and Dutch Development Assistance, London: Routledge, 2007, pp 58-61. 
${ }^{47}$ Interview, staff members at ECORYS Nederland, Rotterdam, 22 September 2009. It is remarkable that two papers by DEK staff members (Harth \& J Waltmans, 'Behind the Façade’; Waltmans, 'Behind the Façade') on the need for political economy analyses of the reality 'behind the façade' do not mention SGACA even once. Details of interviews and interviewees are included in Schakel et al., 2010: Annex II.

${ }^{48}$ Ministry of Foreign Affairs, Framework for Strategic Governance and Corruption Analysis (SGACA): Designing Strategic Responses Towards Good Governance, The Hague: Ministry of Foreign Affairs, 2008 , p 10.

${ }^{49}$ The similarity between Drivers of Change and SGACA is due, in part, to the involvement of Sue Unsworth, former Chief Governance Advisor at DFID, as a consultant in the process of setting up the SGACA framework.

${ }^{50}$ Ministry of Foreign Affairs, Framework for Strategic Governance and Corruption Analysis, pp 6-7.

${ }^{51}$ Ibid,p 27.

${ }^{52}$ Interviews, staff members at ECORYS Nederland, Rotterdam, 22 September 2009; staff members/consultants at Clingendael Institute, The Hague, 2 October and 10 November 2009.

${ }^{53}$ Interview, staff members at ECORYS Nederland, Rotterdam, 22 September 2009.

${ }^{54}$ ECORYS Nederland, Strategic Governance and Corruption Analysis: Draft End-of-Project Review, Rotterdam: ECORYS Nederland, 2009, p 28.

55 Telephone interview, senior consultant, 20 January 2010.

${ }^{56}$ Personal communication by a staff member of the Human Rights, Good Governance and Humanitarian Aid Department, The Hague, 2 September 2010.

${ }^{57}$ World Bank, Managing Development: The Governance Dimension. A Discussion Paper, Washington, D.C.: mimeo,1991, p 3.

${ }^{58}$ World Bank, Building Institutions for Market, p 3.

${ }^{59}$ Cf B Fine, 'Neither the Washington nor the Post-Washington Consensus: An Introduction', in B Fine, C Lapavitsas \& J Pincus (eds), Development Policy in the Twenty-First Century: Beyond the Post-Washington Consensus, London: Routledge, 2003, p 14.

${ }^{60}$ World Bank, Building Institutions for Market, p 99.

${ }^{61}$ World Bank, Economic Growth in the 1990s: Learning from a Decade of Reform, Washington, D.C.: World Bank, 2005, p 298.

62 Ibid, pp 262-5.

${ }^{63}$ World Bank, The Political Economy of Policy Reform: Issues and Implications for Policy Dialogue and Development Operations, Report 44288-GLB, Washington, D.C.: World Bank, 2008; V Fritz, K Kaiser \& B Levy, Problem-Driven Governance and Political Economy Analysis: Good Practice Framework, Washington, D.C.: World Bank, 2009.

${ }^{64} \mathrm{~S}$ Unsworth, Focusing Aid on Good Governance: Can Foreign Aid Instruments Be Used to Enhance 'Good Governance' in Recipient Countries? GEG Working Paper 2005/18, 2005, p 8, at

http://www.globaleconomicgovernance.org/wp-content/uploads/Unsworth\%20-

\%20Focusing\%20Aid\%20on\%20Good\%20Governance.pdf (accessed 7 October 2011).

${ }^{65}$ World Bank, The Political Economy of Policy Reform, p 10.

${ }^{66}$ Ibid, pp 11-13.

${ }^{67}$ Ibid, pp 11, 43-50.

${ }^{68}$ Ibid, p 16.

${ }^{69}$ Fritz et al, Problem-Driven Governance and Political Economy Analysis, p vii.

${ }^{70}$ Ibid, p 1.

${ }^{71}$ Ibid, pp 40-4.

${ }^{72}$ Ibid, p 7.

${ }^{73}$ Ibid, p 12.

${ }^{74}$ Ibid, p 23.

${ }^{75}$ Ibid, pp 17-21.

${ }^{76}$ Unsworth, Focusing Aid on Good Governance, p 8.

${ }^{77}$ A good summary of the criticism has been summarised by N Alexander, 'Judge and Jury: The World Bank’s Scorecard for Borrowing Governments', in Social Watch, Social Watch Report 2004: Fear and Want, Obstacles to Human Security, Montevideo: Instituto del Tercer Mundo, 2004, pp 17-23, at http://www.socwatch.org/sites/default/files/pdf/en/judgeandjury2004_eng.pdf (accessed 7 October 2011).

${ }^{78}$ International Development Association, IDA: The Platform for Achieving Results at the Country Level, Report from the Executive Directors of the International Development Association to the Board of Governors, 28 February 2008, pp 43-5, at http://siteresources.worldbank.org/IDA/Resources/Seminar\%20PDFs/734491172525976405/FinalreportMarch2008.pdf (accessed 7 October 2011).

${ }^{79}$ Ferguson, The Anti-Politics Machine; J Harriss, Depoliticizing Development: The World Bank and Social Capital, New Delhi: LeftWord, 2001. 
${ }^{80}$ Unsworth, 'What's Politics Got to Do with It?'

${ }^{81}$ Raymond Apthorpe, quoted by R Eyben, 'Labelling People for Aid', in J Moncrieff and R Eyben (eds), The Power of Labelling: How People are Categorized and Why it Matters, London: Earthscan, 2007, p 22.

${ }^{82}$ De Haan \& Everest-Phillips, Can New Aid Modalities Handle Politics?, p 15.

${ }^{83}$ Ferguson, The Anti-Politics Machine.

\section{Notes on Contributor}

Wil Hout is Professor of Governance and International Political Economy at the International Institute of Social Studies, Erasmus University Rotterdam. His research interests relate to international relations, development assistance and issues of ('good') governance. He is the author of Capitalism and the Third World (Edward Elgar, 1993), The Politics of Aid Selectivity (Routledge, 2007) and (co-)editor of six volumes and special journal issues, most recently of Governance and the Depoliticisation of Development (with Richard Robison, Routledge, 2009) and 'Governance, Development and the South: Contesting EU Policies', Third World Quarterly 31(1), 2010. He has published articles in, among others, the European Journal of International Relations, Development and Change, the Journal of Development Studies, Critical Asian Studies and Acta Politica: International Journal of Political Science. 